\title{
Production of Enzyme Modified Ras Cheese
}

\author{
El Neenay, Marawa; Awad,S.A; Abbas,Malak and Attia, I.A. ${ }^{1}$
}

\begin{abstract}
In mature cheese, the developement of flavor and texture is largely controlled by intricate biochemical reactions. In these reactions, the proteins, lactose and fats inthe curd are degraded principally by the activities of starter cultures and their enzymes. The dairy researchers developed the enzyme modified cheese (EMC), which are defined as concentrated cheese flavor produced enzymaticaly from cheese of various ages and are used as an ingredient in processed food. An important objective of the present study was an attempt to relate the sensory properties of EMC to the level of key flavor active ingredients. Enzyme modified cheese are natural flavor ingredients manufactured through the addition of a complement of proteolytic and lipolytic enzymes.
\end{abstract}

In this study six different enzyme modified cheese slurry were prepared using two different cultures Lactococcus lactis subsp lactis and Lactococcus lactis subps cremoris (R704) or Lactobacillus casei (R82), lipase, proteases or bovine pepsin and compared with control one .

The results of these trials showed that the using of lipase with bovine pepsin is better than using lipase with protease, Also using culture $\mathbf{R 8 2}$ gave a better results than culture R704 depending on the chemical constituents and sensory point of view.

\section{INTRODUCTION}

Hard cheese ripening time is about 6-12 months. During ripening, the conditions of temperature and humidity are controlled carefully to promote the development of the desirable microbial flora and the secretion of the enzymes responsible for the biochemical changes during ripening. This ripening process is expensive process and difficult to control. The dairy industry has to supply a year-round demand for cheese from a highly seasonal production (Fedrick 1987). Therefore, the development of an efficient way to reduce the ageing time would result in significant saving to the cheese industry (El-Soda 2002). The dairy researchers tried to reduce the maturation costs by applying some methods to accelerate the cheese ripening. The major disadvantage of this technology is the difficulty of controlling the process. In addition, manufacturers are also looking for new methods for the production of a wider variety of cheese flavors.

Recently, the Egyptian Organization for Standardization and Quality Control published new standards indicating that different cheese varieties must be made from pasteurized milk. The pasteurized milk cheeses are poor in flavor with longer ripening time when compared to raw milk cheeses (Singh et al., 2003). Novel approaches are needed to "restore" flavor of traditional Egyptian cheeses in those made from pasteurized milk.

The dairy researchers developed the enzymemodified cheeses (EMC), which are defined as concentrated cheese flavors produced enzymaticaly from cheeses of various ages and are used as an ingredient in processed foods, where they provide a cost-effective alternative to natural cheese (Moskowitz and Noelck 1987; Kilcawley et al., 1998). The EMC can be used as the sole source of cheese flavor to intensify an existing cheese taste, or to impart a specific cheese character to a blander product (Kilcawley et al., 1998). Their main applications are in processed cheese, analogue cheese, cheese spreads, snack foods, soups, sauces, biscuits, dips and pet foods. The major advantages of the EMC compared to other cheese flavor ingredients are: low production costs, good consistency, high flavor intensity, diverse flavor range, extended shelf- life, low storage costs and increased functionality. By using both aged cheese and EMC, it is possible to alleviate shortages of mature cheese at different times caused by the seasonal nature of production. The blend of young cheese and the appropriate EMC, produces a highquality yet economical processed cheese with appropriate performance characteristics and flavor (Kilcawley et al., 1998, 2000).

This study is an attempt to produce enzymes modified Ras cheese (EMC) with strong flavor in order to produce cheap processed Ras cheese with characteristics similar to those made using aged cheese.

\section{MATERIALS AND METHODS}

\section{Culture}

Commercial lactic culture, (DVS R704, Chr. Hansen's Lab., Denmark), contains Lactococcus lactis subsp lactis and Lactococcus lactis subsp cremoris was added at level of $150 \mathrm{mg} / \mathrm{kg}$ of cheese, whereas strain Lactobacillus casei R82 was obtained from Laboratory of microbial biochemistry, Department of Dairy Science and Technology, Agriculture college, Alexandria University. Lipase powder was obtained from dairy land food laboratories Wisconsin, USA, whereas Protease and bovine pepsin were obtained from Sigma Aldrich, Germany.

\footnotetext{
${ }^{1}$ Dairy science Dept. Fac. of Agric. Alexandria Univ. Received May 16, 2013, Accepted June 27, 2013
} 


\section{Strain preparation for slurries}

Frozen cultures (R82) were quick thawed at $37^{\circ} \mathrm{C}$, sub cultured in MRS broth. The cells were harvested when their growth reach to the early stationary phase (about $18 \mathrm{~h}$ ) at $7000 \mathrm{rpm}$ for $15 \mathrm{~min}$ at $4^{\circ} \mathrm{C}$. The obtained pellet was washed twice with $0.01 \mathrm{M}$ potassium phosphate buffer $\mathrm{pH} 7.0$ and suspended in the same buffer to about $\approx$ one Optical Density $\left(\sim 1 \times 10^{8} \mathrm{cfu} / \mathrm{g}\right)$. The suspension was stored at $-20^{\circ} \mathrm{C}$ until use. wherease culture R704 was used as DVS with recommended dosage.

\section{Ras Cheese making procedure}

Young Ras cheese (10 days ) was obtained from the dairy pilot plant at Department of Dairy Science and Technology, Faculty of Agriculture, Alexandria University. The cheese was made according to (Hofi, et al, 1970) as following: raw whole cow milk was obtained from the dairy farm at the Alexandria University. Raw cow milk was pasteurized at $74{ }^{\circ} \mathrm{C}$ for $15 \mathrm{~s}$. A starter culture (DVS culture, $0.15 \mathrm{~g} / \mathrm{Kg}$ ) was added to milk at $32{ }^{\circ} \mathrm{C}$. The inoculated milk is held for $60-75 \mathrm{~min}$ at $32^{\circ} \mathrm{C}$ and then liquid rennet (Chymax-II 500: Chr. Hansen's Lab., Denmark) was added to coagulate the milk within $30 \mathrm{~min}$. The coagulum was cut into cubes $(\sim 2 \mathrm{~cm})$ and the curd was allowed to rest in the whey for 5-10 min. The curd was scalded to $45^{\circ} \mathrm{C}$ through $45 \mathrm{~min}$ and held at this temperature for 15 more minutes. One third of whey was drained when its acidity reached to $0.14 \%$ as lactic acid, and then $3 \%$ of salt from weight of milk was added and mixed with curd for $15 \mathrm{~min}$. The obtained curd was hooped and pressed for 4 $\mathrm{h}$, and then the cheese was turned and repressed for 12 more hours. This young cheese was stored at $10-12^{\circ} \mathrm{c}$ and relative humidity 70 for 10 days.

\section{Preparation of cheese slurry}

For one $\mathrm{kg}$ of young ground Ras cheese, $100 \mathrm{ml}$ of sterile water were blended to obtain a control slurry in a sterile blender jar. Then the slurry was transferred into a sterile wide mouth bottle, capped and incubated at $30^{\circ} \mathrm{c}$ for 7 and 14 days.

The other treatments were as following:

Treatment1 $(\operatorname{Tr} 1)$ : lipase and protease

Treatment $2(\operatorname{Tr} 2)$ : lipase + protease + culture R 82

Treatment $3(\operatorname{Tr} 3)$ : lipase + protease + culture R704

Treatment $4(\operatorname{Tr} 4)$ : lipase + bovine pepsin

Treatment $5(\operatorname{Tr} 5)$ : lipase + bovine pepsin + culture R82

Treatment $6(\operatorname{Tr} 6)$ : lipase + bovine pepsin + culture R704

Lipase concentration was $0.375 \mathrm{mg} / \mathrm{kg}$ cheese whereas protease or bovine pepsin were $150 \mathrm{mg} / \mathrm{kg}$ cheese. Three $\mathrm{ml}$ of suspended culture about $10^{8} \mathrm{cfu} / \mathrm{ml}$ was added to $1 \mathrm{~kg}$ of cheese.

\section{Chemical analysis}

The total protein content and the water soluble nitrogen were determined by Kjeldahl (AOAC, 2003), Fat content by Gerber method (AOAC, 2003). A Corning flat surface combination electrode was used to measure the $\mathrm{pH}$. Titratable acidity (TA) was determined by the method developed by Lau, et al (1991). TA was expressed as percentage lactic acid content of cheese by weigh. The moisture content was determined using air oven (AOAC, 2003). Salt content was determined in cheese according to kosikowski (1978),

The concentration of free amino acids in the water soluble extracts were determined in duplicate using the method of Doi et al 1981 and modified by Folkertsma and Fox1992). Because the most abundant free amino acids present in cheese are Leucine and glutamic acid (Thomas and Prichard, 1987), The $\mathrm{A}_{507}$ was converted to $\mathrm{mM}$ leucine from a prepared standard curve with leucine. The concentration of free fatty acid were determined according to kosikowski (1978), expressed as $\mathrm{ml}$ of $1.0 \mathrm{~N}$ alkali/ $100 \mathrm{~g}$ of cheese fat.

\section{Microbiological analysis}

The cheese slurry or enzyme modified cheese slurry $\left(E_{\mathrm{S}}\right)$ were aualysed for their countes al Lactic acid bacteria using de Man Rogosa sharpe Agar medium MRS as described by Bridson, (1990). The plates were incubated at $37^{\circ} \mathrm{C}$ for 48 hours.

Coliform bacteria were enumerated using Violet Red Bile Agar medium according to Difco (1984). The plates were incubated at $37^{\circ} \mathrm{C}$ for 24 hours .

While Sabouraud Agar medium was used for the enumeration of yeasts and moulds as recommended by Difco (1984). The plates were incubated at room temperature $\left(20-25^{\circ} \mathrm{C}\right)$ for $5-7$ days.

\section{Organoleptic evaluation of cheese slurries}

The cheese slurries were tested by a test panel for flavor development by 10 people differs in their classification (staff members, students and employers) using the method of Meilgaard et al 1991.

\section{RESULTS AND DISCUSSION}

The chemical composition of young Ras cheese used for preparing the enzymes modified cheese were: $25.5 \%$ fat, $22.5 \%$ protein, $44.8 \%$ moistures, $2.9 \%$ salt, PH 5.9 and the acidity was $1.55 \%$.

Table 1 shows the chemical composition of Enzyme modified Ras cheese (EMC)

The $\mathrm{pH}$ values was 5.87 in control at zero time and decreased to 5.43 in $\operatorname{Tr} 3$ after two weeks, the range value was between 5.50 to 5.64 for the other treatments. 
The decrease in the EMC $\mathrm{pH}$ was associated with an increase of acidity. The level of salt in EMC varied from 2.36 to 2.8 and this give a specific salty flavor to the final product.

Proteolysis in EMC Ras cheese as determined by the level of soluble nitrogen at $\mathrm{pH} 4.6$ (WSN/TN) or free amino acids determined as mg leucine/100g cheese slurry varied from 1.73 to $3.10 \%$ for WSN/TN and from 100 to $381.21 \mathrm{mg}$ leucine for $100 \mathrm{~g}$ cheese after one week of storage while the control one was $1.31 \%$ WSN/TN and FAAs were $64.97 \mathrm{mg}$ leucine $/ 100 \mathrm{~g}$ cheese (Table 2). The level of proteolysis was increased after two weeks to be varied between 3.1 to $5.32 \%$ in WSP/TN and from 202 to $480 \mathrm{mg}$ leucine/100g cheese while the WSP/TN was 2.66 and FAAs were $151 \mathrm{mg}$ leucine $/ 100 \mathrm{~g}$ in control cheese after two weeks. The level of proteolysis was higher when lipase and bovine pepsin were used with a culture $82(\operatorname{Tr} 5)$ than culture $704(\operatorname{Tr} 6)$. Also the rate of proteolysis was higher when lipase and bovine pepsin were used instead of lipase and protease.

The total fatty acids content, expressed as $\mathrm{ml} \mathrm{KoH}$ $1 \mathrm{~N} / 100 \mathrm{~g}$ of fat in cheese are shown in Table 2 .The rate of lipolysis was increased after two weeks to reach 6.95 $\mathrm{ml} \mathrm{KoH} 1 \mathrm{~N} / 100 \mathrm{~g}$ in the treatment $\mathrm{Tr} 3$ whereas the corresponding value was 3.47 in control cheese. The use of both starters culture R704 or culture R 82 increased the liberation of FFA in EMC cheese than using the enzymes only $(\operatorname{Tr} 1, \operatorname{Tr} 4)$.

Free fatty acids (FFA) are major contributors to the flavor of EMC, (Kileaulry et al, 2006). The latter are released upon lipolysis and the short intermediate chain
FFA ontribute directly to cheese flavor, these short and intermediate shain fatty acids have relatively low perception thresholds and each gives a characteristic flavor note (Noronha et al 2008).

Basic cheese ripening researches showed that starter bacteria have a vital ripening role as well as acidification. This make them an obvious choice as ripening agents to control and accelerate maturation using the natural enzymes of the process .More culture means more production of flavor compounds. The starter cultures are reliable and effective way to increase and enhance the taste impact of most hard cheese and semi-hard cheese varieties (Law 2001).

Data presented in table3 show the microbial counts of Enzyme modified Ras cheese samples. Lactic acid bacteria were found to be $8 \times 10^{7} \mathrm{cfu} / \mathrm{g}$ in fresh Ras cheese slurry. The counts of Lactic acid bacteria were ranged from $9.6 \times 10^{5} \mathrm{cfu} / \mathrm{g}$ to $2 \times 10^{8}$ in other EMC Ras cheese slurry. The counts of coliform bacteria on Violet Red Bile agar were ranged between $1.6 \times 10^{2}$ and $5 \times 10^{3}$ $\mathrm{cfu} / \mathrm{g}$. The counts on Sabouraud were detected in all samples and ranged between $100 \mathrm{cfu} / \mathrm{g}$ to $4.6 \times 10^{3} \mathrm{cfu} / \mathrm{g}$. The differences of microbiological counts among EMC samples were due to the culture added, moisture and salt contents.

Starter cultures for attenuation and accelerated ripening are select either because they simply make good flavored cheese or because they produce specific flavor notes in cheese models curd (law 2001).

\section{Table 1. Chemical composition of enzyme modified Ras cheese (EMC)}

\begin{tabular}{|c|c|c|c|c|c|}
\hline Treatments & $\begin{array}{l}\text { Storage period } \\
\text { (weeks) }\end{array}$ & pH & $\underset{\%}{\text { Acidity }}$ & $\begin{array}{c}\text { Moisture } \\
\%\end{array}$ & $\underset{\%}{\text { Salt }}$ \\
\hline \multirow{3}{*}{ Control } & Zero time & 5.87 & 1.50 & 50.45 & 2.36 \\
\hline & 1 week & 5.68 & 1.60 & 49.40 & 2.55 \\
\hline & 2 weeks & 5.54 & 1.77 & 47.16 & 2.60 \\
\hline \multirow[t]{2}{*}{ Tr1 } & 1 week & 5.69 & 1.76 & 49.83 & 2.54 \\
\hline & 2 weeks & 5.50 & 1.96 & 48.17 & 2.60 \\
\hline \multirow[t]{2}{*}{ Tr2 } & 1week & 5.83 & 1.70 & 48.07 & 2.59 \\
\hline & 2 weeks & 5.56 & 1.79 & 47.66 & 2.70 \\
\hline \multirow[t]{2}{*}{ Tr3 } & 1week & 5.65 & 1.72 & 49.54 & 2.75 \\
\hline & 2 weeks & 5.43 & 1.78 & 47.55 & 2.80 \\
\hline \multirow[t]{2}{*}{ Tr4 } & 1week & 5.66 & 1.69 & 51.51 & 2.60 \\
\hline & 2weeks & 5,56 & 1.74 & 50.71 & 2.71 \\
\hline \multirow[t]{2}{*}{ Tr5 } & 1week & 5.94 & 1.53 & 49.32 & 2.64 \\
\hline & 2weeks & 5,64 & 1.70 & 47.68 & 2.60 \\
\hline \multirow[t]{2}{*}{ Tr6 } & 1week & 5.62 & 1.69 & 47.24 & 2.57 \\
\hline & 2weeks & 5.55 & 1.73 & 46.71 & 2.60 \\
\hline
\end{tabular}

(Tr1) : lipase and protease

$(\operatorname{Tr} 2)$ : lipase + protease + culture $\mathrm{R} 82$

$(\mathrm{Tr} 3)$ : lipase + protease + culture R704
(Tr4) : lipase + bovine pepsin

$(\operatorname{Tr} 5)$ : lipase + bovine pepsin + culture R82

(Tr6) : lipase + bovine pepsin + culture R704 
Table 2. Contents of water soluble protein, Free amino acidsand Free Fatty acids in enzyme modified Ras cheese

\begin{tabular}{|c|c|c|c|c|}
\hline Treatments & $\begin{array}{c}\text { Storage period } \\
\text { (weeks) }\end{array}$ & Wsp/Tp & $\begin{array}{c}\text { FAA } \\
\text { mg leucine } / 100 \mathrm{~g}\end{array}$ & $\begin{array}{c}\text { FFA } \\
\mathrm{mlKoH} / 100 \mathrm{~g}\end{array}$ \\
\hline \multirow{3}{*}{ Control } & Zero time & 0.87 & 30.65 & 175 \\
\hline & 1 week & 1.31 & 64.97 & 2.99 \\
\hline & 2weeks & 2.66 & 251.26 & 3.47 \\
\hline \multirow[b]{2}{*}{ Tr1 } & 1 week & 1.73 & 189.90 & 4.35 \\
\hline & 2 weeks & 3.10 & 202.29 & 4.41 \\
\hline \multirow[b]{2}{*}{$\operatorname{Tr} 2$} & 1 week & 2.65 & 381.21 & 5.38 \\
\hline & 2 weeks & 5.32 & 449.90 & 5.86 \\
\hline \multirow[b]{2}{*}{ Tr3 } & 1 week & 2.60 & 144.14 & 5.35 \\
\hline & 2 weeks & 3.55 & 208.29 & 6.95 \\
\hline \multirow[b]{2}{*}{ Tr4 } & 1 week & 2.61 & 100.34 & 3.48 \\
\hline & 2 weeks & 3.10 & 279.90 & 5.92 \\
\hline \multirow[b]{2}{*}{ Tr5 } & 1 week & 3.10 & 201.62 & 4.37 \\
\hline & 2 weeks & 4.43 & 480.77 & 5.90 \\
\hline \multirow[b]{2}{*}{ Tr6 } & 1 week & 2.61 & 140.04 & 5.89 \\
\hline & 2 weeks & 4.43 & 378.50 & 5.92 \\
\hline
\end{tabular}

(Tr1) : lipase and protease

$(\operatorname{Tr} 2)$ : lipase + protease + culture R 82

(Tr3) : lipase + protease + culture R704

(WSP); water soluble protein

(Tr4) : lipase + bovine pepsin

(Tr5) : lipase + bovine pepsin + culture R82

(Tr6) : lipase + bovine pepsin + culture R704

(FAA): Free amino acids

(FFA): Free Fatty acidsin

(EMC): modified Ras cheese

\section{Table 3. Microbial counts (CFU/g) in enzyme modified Ras cheese (EMC)}

\begin{tabular}{|c|c|c|c|c|}
\hline Treatments & $\begin{array}{l}\text { Storage periode } \\
\text { (weeks) }\end{array}$ & $\begin{array}{l}\text { Lactic acid bacteria } \\
\text { Cfu/g }\end{array}$ & $\begin{array}{c}\text { Coliform } \\
\text { Cfu/g }\end{array}$ & $\begin{array}{l}\text { Yeast \&mold } \\
\text { Cfu/g }\end{array}$ \\
\hline \multirow{3}{*}{ Control } & Zero time & $8 \times 107$ & $3 \times 102$ & $4.5 \times 102$ \\
\hline & 1 week & $7.0 \times 107$ & $5 \times 103$ & $3 \times 102$ \\
\hline & 2weeks & $1.12 \times 106$ & $2 \times 102$ & $6.1 \times 102$ \\
\hline \multirow[b]{2}{*}{ Tr1 } & 1 week & $9.6 \times 105$ & $1.65 \times 102$ & $2.88 \times 102$ \\
\hline & 2 weeks & 4 X 106 & $6 . X 102$ & $2 \times 102$ \\
\hline \multirow{3}{*}{ Tr2 } & 1 week & $4 \times 107$ & $2 \times 102$ & $5 \times 102$ \\
\hline & 2 weeks & 2. X 108 & $2.3 \times 102$ & $2.7 \times 102$ \\
\hline & 1 week & $2.3 \times 106$ & $1.78 \times 102$ & $4.6 \times 103$ \\
\hline \multirow[t]{2}{*}{ Tr3 } & 2 weeks & $5 \times 107$ & $4.1 \times 102$ & $1 \times 102$ \\
\hline & 1 week & $4 \times 107$ & $3.4 \times 102$ & $6 \times 102$ \\
\hline Tr4 & 2 weeks & $1.2 \times 108$ & $1.0 \times 102$ & $2.5 \times 102$ \\
\hline \multirow{3}{*}{ Tr5 } & 1 week & $6.5 \times 106$ & $4 \times 102$ & $3.4 \times 102$ \\
\hline & 2 weeks & $6.5 \times 107$ & $2 \times 102$ & $2 \times 102$ \\
\hline & 1 week & $2.07 \times 107$ & $2.65 \times 102$ & $3 \times 102$ \\
\hline Tr6 & 2 weeks & $7 \times 108$ & $1 \times 102$ & $1.6 \times 102$ \\
\hline
\end{tabular}

An important objective of the present study was an attempt to relate the sensory properties of EMC to the level of key flavor active ingredients. Enzyme modified cheese are natural flavor ingredients manufactured through the addition of a complement of proteolytic and lipolytic enzymes (Forde and Fitzgerald, 2000).
Panellists were asked to rank the products based on preference for flavor and mouth feel using the methods of Meilgaard et al (1991). The assessors were instructed to evaluate the sample, using a score from 1 (most preferred sample) to 3 (least preferred sample). Panelists were also instructed to report any descriptors 
of their observations of the sensory characteristics for cheese samples.

Lowering the $\mathrm{pH}$ of EMC had the effect not only for increasing the intensity of flavor but also changing the perception of the mouth feel character of the product. Panelists described the lower $\mathrm{pH}$ cheeses as smoother.

There was very little difference between ranking scores of the treatment from the same group ( $\operatorname{Tr} 1, \operatorname{Tr} 2$ $, \operatorname{Tr} 3$ or $\operatorname{Tr} 4, \operatorname{Tr} 5, \operatorname{Tr} 6)$ but cheese being described by panelists as having slight acid or slight bitter especially when the culture R 704 was used. while the control cheese was characterized as slight flat flavor after two weeks. Definite bitter flavor was noticed after two weeks of incubation especially when culture R 704 was added with lipase and pepsin (Tr 6). From the sensory point of view, the best treatment was $\operatorname{Tr} 5$ after two weeks. Which described by panelists as having strong and pleasant flavor .

\section{REFERENCES}

AOAC (2003). Official Methods of analysis. Arlington, VA: Association of Official Analytical Chemists.

Bridson, E.Y (1990). T he Oxoid M, $6^{\text {th }}$ Ed. Unipath Ltd, ade road , Basing stoke RG240PN.

Difco, (1984)" Manuel of dehydrated culture, media and reagent for microbiological and clinical laboratories" Detroit, Michigan ,V.S.A .

Doi, E., Shibata-D. and Matoba, T. (1981). Modified colorimetric ninhydrin methods for peptidase assay. Analytical Biochemistry; 118 (1) 173-184.

El Soda M. (2002). Accelerated cheese ripening. Pages 327329 in Encyclopedia of Dairy Science. H. Roginski, J. W. Fuquay, and P. F. Fox, ed. Academic Press, London, UK.

Fedrick, I. (1987). Technology and economics of the accelerated ripening of Cheddar cheese. Australian $\mathbf{J}$ of Dairy Techno, 42, 33-36.

Folkertsma, B. \& Fox, P. F. (1992). Use of the cadmium-ninhydrin reagent to assess proteolysis in cheese during ripening. J of Dairy Res, 59:217.
Forde, A. and Fitzgerald, G. F.(2000). Biotechnological approaches to the understanding and improvement of mature cheese flavor . Food biotechnology 11: 484.

Hofi, A. A., Youssef, E. H. Ghoneim, M. A., \& Tawab, G. A. (1970). Ripening changes in Cephalotyre "Ras" cheese manufactured from raw and pasteurised milk with special reference to flavour. J of Dairy Sci, 53, 1207-1212.

Kilcawley, K.N; Wilkinson , M.G. and Fox, P.F. (2006). A novel two stage process for the production of enzymes modified cheese. Food research International $39: 619$.

Kilcawley K. N., Martin G. Wilkinson and Patrick F. Fox (1998). Enzyme-Modified cheese. International Dairy J, 8, 1-10.

Kilcawley, K. N., M. G. Wilkinson and P. F. Fox (2000). A survey of the composition and proteolytic indices of commercial enzyme-modified Cheddar cheese. International Dairy J, 10, 181-190.

Kosikowski, F.V.(1978) Cheese and Fermented Milk Food $2^{\text {nd }}$ Edation. Pub: Kosikowski, F.V. and associates.N.Y.

Lau, K. Y., Barbano, D. M., \& Rasmussen, R. R. (1991). Influence of pasteurization on protein breakdown in Cheddar cheese during ripening. J, of Dairy Sci, 74, 727740.

Law ,B. A. (2001) . Controlled and accelerated cheese ripening : the research base for new technologies. International Dairy journal .11:383

Meilgaard, M. M; Civile, G .V . and Carr, T .(1991). Descriptive analysis techniques (3rd ed) Sensory evaluation techniques. New york, NY. CRC Press.

Moskowitz, G. J. and Noelck, S. S. (1987). Enzyme modified cheese technology. Journal of Dairy Science 70, 17611769.

Noronha, N; Cronin,E ,Denis A ; Dolores O'Riordan, E. and Michelle O'Sullivan (2008). flavouring of imitation cheese with enzyme-modified cheeses (EMCs) :Sensory impact and measurement of aroma active short chain fatty acids (SCFAs). Food Chemistry 106:905

Singh, T. K., Drake, M. A., and Cadwallader, K. R. (2003). Flavour of Cheddar cheese: A chemical and sensory perspectives. Comprehensive Reviews in Food Science and Food Safety, 2, 139-162.

Thomas, T.D. and Pritchard, G.G. (1987). Proteolytic enzymes of dairy starter cultures. FEMS Microbiol. Rev., 46, 245268. 


$$
\begin{aligned}
& \text { الملتخص العربي } \\
& \text { إنتاج الجبن الراس المعامل إنزيمياً } \\
& \text { مروة النعناعي, سامح علي عوض, ملك عباس حلمي, ابراهيم عطية } \\
& \text { إن زيادة مركبات الطعم وخواص القوام أثناء تسوية الجبن مرتبطة الليبيز مع انزيمات محللة للبروتين مـن مصدر ميكروبى(البروتييز) او }
\end{aligned}
$$

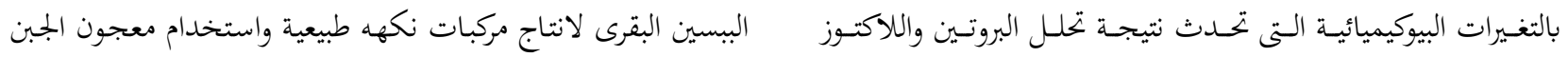

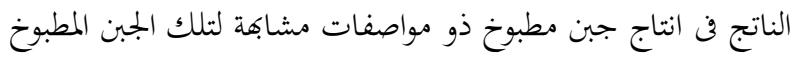

$$
\begin{aligned}
& \text { المصنع من جبن مسوى مع رخص تكلفة إنتاجه. } \\
& \text { وقد تم تصنيع } 6 \text { معاملات مختلفة واوضحت النتائج مـن هـذه }
\end{aligned}
$$

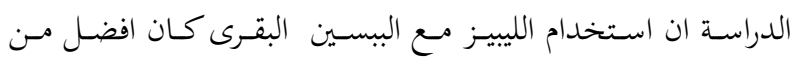

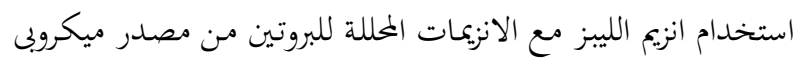

$$
\begin{aligned}
& \text { كما ان إستخدام البادئ Lactobacillus casei (culture R82) } \\
& \text { cremoris أعطى نتائج افضل من استخدام البادئ } \\
& \text { Lactococcus lactis subsp lactis and Lactococcus subsp } \\
& \text { glactis ～(culture R 704) } \\
& \text { والدهن والتى تتاثر بدرجة كبيرة بالبادئات المستخدمة والإنزيمات. } \\
& \text { وكلمـا إخفضضـت فـترة تخزين الجهبن مـع وصـولها لدرجـة التسـوية } \\
& \text { المطلوبة كان لها مردود إقتصادي كبير. ولهذا ابتهت الأبحاث الحديثة وصنئ }
\end{aligned}
$$

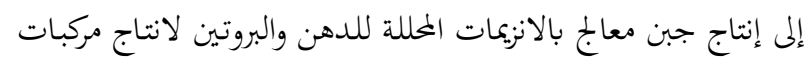

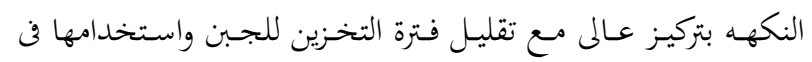

$$
\begin{aligned}
& \text { الاغذية المطبوخة. - مبرة } \\
& \text { تعتبر هذه الدراسة محاولة لانتاج خواص طعم جيدة في معجون } \\
& \text { الجبن الراس وذلك باستخدام نوعين من البادئات بالاضافة الى انزيم } \\
& \text { الكيماوي والتقييم الحسي للناتج النهائي. }
\end{aligned}
$$

